\title{
Energy Scaling Law for Buildings
}

\author{
DAVID HAFEMEISTER \\ California Polytechnic University, San Luis Obispo, California, USA
}

\section{On the occasion of the 80th birthday of Hendrik de Waard}

\begin{abstract}
This paper is an ode to my friend Hendrik. We collaborated on hyperfine interactions from 1962 to 1984, when he was colleague and friend. Since then I have been working on the Physic's of Societal Issues (Springer Verlag, 2003). The paper below models energy use in buildings, which could save considerable energy with well-designed buildings.
\end{abstract}

Key words: free temperature, building balance point, energy lossiness, superinsulated houses.

Energy needs of large buildings are mainly driven by internal heat gains from equipment, people and lighting, while houses are mainly driven by heat loss through their envelopes. This causes large buildings to be fairly independent of climate while small buildings have energy bills proportional to the degree-days of the heating and cooling. The physical difference between large and small buildings is easily seen with scaling laws. Scaling estimates reveal the basics of diverse phenomena such as critical masses for nuclear weapons, animal bone-size and eating habits of animals. Our scaling model determines the "free temperature" of buildings of all sizes, as well as superinsulated houses. It is true that under very extreme circumstances a house can be heated with a candle or "two cats fighting".

Heat-loss is proportional to a building's surface area, $L^{2}$, and the temperature difference $\Delta T$ between inside and outside,

$$
\left.\frac{\mathrm{d} Q}{\mathrm{~d} t}\right]_{\mathrm{loss}}=K L^{2} \Delta T
$$

where $K$ is thermal conductivity. On the other hand, the internal gain is proportional to the building's volume (floor area times a fixed ceiling height of about $3 \mathrm{~m}$ )

$$
\left.\frac{\mathrm{d} Q}{\mathrm{~d} t}\right]_{\text {gain }}=G L^{3},
$$

where $G$ is energy gain per unit volume. A typical house has about $1 \mathrm{~kW}$ of free heat $(3500 \mathrm{Btu} / \mathrm{h})$, while office buildings have internal gains of about $F=66 \mathrm{~W} / \mathrm{m}^{2}$ 
(6 W/ $\mathrm{ft}^{2}$ ). The volume-gain $G$ is $F / H$ where $H$ is the height of a floor, obtained from

$$
\left.\frac{\mathrm{d} Q}{\mathrm{~d} T}\right]_{\text {gain }}=G L^{3}=F n L^{2}=F L^{3} / H
$$

where the number of floors $n=L / H$. Because of internal gains, the inside of a typical unheated house is $2^{\circ} \mathrm{C}\left(3-4^{\circ} \mathrm{F}\right)$ warmer than the outside. This temperature difference is needed to force excess heat through the walls to maintain a constant inside temperature. An extreme example is a blanket placed over a light bulb, blocking heat-flow and raising the temperature to cause a fire. Free temperature, $\Delta T_{\text {free }}$, in buildings saves considerable heat energy.

Let's consider the simple case of walls without mass and specific heat, ignoring the time dependence of warming-up and cooling-down. For a building without a furnace, the gains and losses are equal,

$$
\begin{aligned}
\left.\frac{\mathrm{d} Q}{\mathrm{~d} t}\right]_{\text {gain }} & \left.=\frac{\mathrm{d} Q}{\mathrm{~d} t}\right]_{\text {loss }}=G L^{3}=K L^{2} \Delta T_{\text {frec }} \text { or } \\
\Delta T_{\text {free }} & =(G / K) L .
\end{aligned}
$$

Large free temperatures are observed in several situations. Big buildings (large $L$ ), buildings with very good insulation (small $K$ ) and buildings with large internal heat loads $(G)$ can be too warm. In our case, the scaling model is applied to large buildings (big $L$ ) and superinsulated houses with considerable insulation (small $K$ ). Thermostats do not call for heat until the outside temperature, $T_{\text {outside, }}$ drops $\Delta T_{\text {frse }}$ below the thermostat temperature, $T_{\text {thermostat }}$. The outside temperature when the furnace comes on (ignoring the time lag from thermal mass) is called the "balance point of a building", which for a typical building in the US is

$$
T_{\text {ballance }}=T_{\text {thermosiat }}-\Delta T_{\text {free }}=20^{\circ} \mathrm{C}-2^{\circ} \mathrm{C}=18^{\circ} \mathrm{C}\left(68^{\circ} \mathrm{F}-3^{\circ} \mathrm{F}=65^{\circ} \mathrm{F}\right) \text {. }
$$

At the balance point, the internal heat gain without the furnace balances the heat losses. As building sizes increase, the increased $\mathrm{d} Q / \mathrm{d} t]_{\text {gain }}$ increases free temperature, $\Delta T_{\text {free }}=(G / K) L$, and lowers the balance point when heat is needed. At outside temperatures below the balance point, the net heat-loss rate is

$$
\begin{aligned}
\left.\frac{\mathrm{d} Q}{\mathrm{~d} t}\right]_{\text {net }} & \left.\left.=\frac{\mathrm{d} Q}{\mathrm{~d} t}\right]_{\text {loss }}-\frac{\mathrm{d} Q}{\mathrm{~d} t}\right]_{\text {gain }} \\
& =K L^{2}\left[\Delta T-\Delta T_{\text {free }}\right]=K L^{2}[\Delta T-(G / K) L] .
\end{aligned}
$$

Note that the length $L$ appears in two ways: the multiplicative $K L^{2}$ term for the "lossiness" of the building increases loss with increased conductivity and size. The subtractive term, $G L / K$, for free temperature, reduces losses by increasing the free temperature and lowering the balance point. Increased thermal resistance saves energy in three ways. (1) Reduced losses from reduced conductivity $K$. (2) The 
subtractive free temperature allows you to run the house at an effectively lower temperature. (3) Additional thermal resistance saves considerable energy when examining the degree-day distribution function. For the days when $T_{\text {outside }}$ is greater than the balance point of the building, $100 \%$ of the energy is saved. On other days, there is a fractional energy savings. If the free temperature from a superinsulated house is $14^{\circ} \mathrm{C}\left(25^{\circ} \mathrm{F}\right)$, the balance point is $6^{\circ} \mathrm{C}(20-14)$. If the outside temperature drops to $-12^{\circ} \mathrm{C}$, the $\left[\Delta T-\Delta T_{\text {free }}\right.$ ] term has a value of $18^{\circ} \mathrm{C}(32-14)$ and not $30^{\circ} \mathrm{C}(32-2)$, saving $40 \%$ of an already reduced rate from the lower $K$ value.

As an example, let the internal energy of a typical house be $1 \mathrm{~kW}(3500 \mathrm{Btu} / \mathrm{h})$. For a lossiness of $K L^{2}=0.5 \mathrm{~kW} /{ }^{\circ} \mathrm{C}\left(1000 \mathrm{Btu} / \mathrm{h}-{ }^{\circ} \mathrm{F}\right)$, the free temperature is obtained from a heat balance of gain and loss;

$$
\begin{aligned}
& \mathrm{l} \mathrm{kW}=K L^{2} \Delta T_{\text {iree }}=\left(0.5 \mathrm{~kW} /{ }^{\circ} \mathrm{C}\right) \Delta T_{\text {free }}, \quad \text { gives } \\
& \Delta T_{\text {free }}=2^{\circ} \mathrm{C} \text { and } T_{\text {balance }}=20-2=18^{\circ} \mathrm{C} .
\end{aligned}
$$

A superinsulated house with twice the free heat of $2 \mathrm{~kW}(7000 \mathrm{Btu} / \mathrm{h})$, and $20 \%$ of its former lossiness $\left(K L^{2}=0.1\right)$ has a $\Delta T_{\text {frue }}$ that is $2 \times 5=10$ times larger. The $\Delta T_{\text {iree }}$ is $20^{\circ} \mathrm{C}(2 / 0.1)$ and the balance point is $(20-20)=0^{\circ} \mathrm{C}$. This superinsulated house would not need heat during the late fall and early spring. Even on a cold day of $-18^{\circ} \mathrm{C}$, the building would only need one tenth the heat formerly used because lossiness is reduced by a factor of 5 and the temperature difference is only one-half as great $\left(18\right.$ vs $\left.38^{\circ} \mathrm{C}\right)$. Some super-super insulated houses in Saskatchuwan, Canada $(5600)^{\circ} \mathrm{C}$-dd) use only $\$ 30$ of natural gas to get through the winter. It is possible for a very tight house with extreme small lossiness to operate using the heat of "two cats fighting", but economics makes this only a pedagogical example. 